\title{
Między wierszami, czyli adaptacja nietypowa
}

Images vol. IX/no. 17-18

Poznań 2011

ISSN 1731-450X

Jestem reżyserem filmowym i grafikiem - pisanie nie jest moją ulubioną dziedziną. Wprawdzie piszę scenariusze, ale polega to głównie na notowaniu wyobrażonych sytuacji i wynikających z nich dialogów. Teksty analityczne, takie jak ten, którego fragment państwu przedstawiam, są dla mnie prawdziwym wyzwaniem i proszę o wyrozumiałość. Mam nadzieję, że dydaktyczny cel tej pracy uświęci środki, jakich użyłem, aby ją wykonać.

$\mathrm{W}$ wielu artykułach i recenzjach omawiających Żurek podkreślano fakt, że ów pełnometrażowy film fabularny powstał z kilkustronicowego zaledwie tekstu literackiego. „Nikt nie spodziewał się, że z ośmiostronicowego opowiadanka Olgi Tokarczuk można zrobić 80-stronicowy scenariusz" [1] - pisała w przekroju Małgorzata Sadowska. Podobne stwierdzenie możemy znaleźć w tekście Barbary Hollender: „Opowiadanie Olgi Tokarczuk z tomu Gra na wielu bębenkach ma zaledwie kilka stron, ale to wystarczyło, aby powstał film” („Rzeczypospolita”[2]. „Scenariusz Żurku powstał na podstawie opowiadania Olgi Tokarczuk, umiejętnie rozbudowanego przez reżysera” - odnotował w „Polityce” Zdzisław Pietrasik[3]. Według Wojciecha Kałużyńskiego: „Sięgając po opowiadanie Żurek Olgi Tokarczuk [...] ośmiostronicową literacką miniaturkę - Brylski ryzykował. A jednak udało się zachować klimat pierwowzoru, a zarazem nadać mu nową jakość” [4].

Podobnie reagowali inni recenzenci, a także sama autorka opowiadania, która wypowiedziała się obszernie na ten temat po premierze filmu. Nic więc dziwnego, że w wywiadach prasowych $\mathrm{i}$ telewizyjnych lub na spotkaniach $\mathrm{z}$ widzami często pytano mnie właśnie o to, jak powstawała adaptacja.

Rozpatrywanie tego w kategoriach „fenomenu” komplementowało mnie oczywiście jako scenarzystę, ale nie dlatego wspominam o tym teraz, niejako tłumacząc się $\mathrm{z}$ wyboru tematu tego tekstu. Pytany wówczas - w toku rozmowy - formułowałem odpowiedzi dość chaotyczne i raczej zdawkowe, a kiedy pojawiła się propozycja, żeby uporządkować i zapisać te przemyślenia, wymuszone potrzebą chwili, nie podjąłem jej. Emocje popremierowe minęly dość szybko, a poza tym brakowało mi wtedy dystansu, niezbędnego przy analizowaniu własnych dokonań.

[1] M. Sadowska, „Żurek”-Święta historia w ludzkim wymiarze, „Przekrój” 2003, nr 39 (3040).

[2] B. Hollender, $Z$ dala od zgiełku, „Rzeczpospolita” 2003, nr 225 (6605).
[3] Z. Pietrasik, Na Ekranie - „Żurek”, „Polityka” 2003, nr 40 (2421).

[4] W. Kałużyński, Żurek, „Film” 2003, nr 10. 
Temat wrócił rykoszetem, kiedy w ubiegłym roku rozpocząłem przygotowania do przewodu doktorskiego w łódzkiej PWSFTviT. Przypadkowo zbiegło się to z faktem, że Żurek, jako jeden z przykładów filmowej adaptacji utworu literackiego, stał się przedmiotem analizy na zajęciach drugiego roku reżyserii i został zaprezentowany jako przykład „adaptacji nietypowej”. Trudno mnie samemu z tą kwalifikacją nie zgodzić się, chociaż trudno też, mimo megalomańskiej pokusy, uznać Żurek za przypadek wyjątkowy. Powstało wiele filmów inspirowanych drobnymi formami literackimi, fragmentami lub wątkami wyjętymi $\mathrm{z}$ większej całości i były one z pewnością wielokrotnie analizowane, czy też opisywane w owym aspekcie „nietypowości”. Uznałem jednak, że skoro ciągle jest „coś na rzeczy”, spróbuję teraz - po kilku latach - możliwie klarownie opisać własny tok myślenia i podzielić się refleksjami, jakie towarzyszyły mojej pracy nad tekstem Olgi Tokarczuk.

Zdaję sobie sprawę, że nie dokonam tu szczególnej prezentacji nieznanych lub dawno zapomnianych prawd. Nie sformułuję także metody, która miałaby skutecznie obowiązywać w tego rodzaju przedsięwzięciach. Mam jednak nadzieję, że autorska relacja z powstawania „nietypowej adaptacji” stanie się w jakimś stopniu pożyteczna w pracy dydaktycznej i być może zachęci przyszłych twórców filmowych do odważnego sięgania po intrygujące, choć na pozór ulotne inspiracje.

Halina i Iwonka

Żurek Olgi Tokarczuk to w pierwszym czytaniu urzekająco prosta, obyczajowa miniatura. Opowiedziana jak na autorkę trochę wyjątkowo, bo na wskroś realistycznie, zmienia jednocześnie emanujący z owej prostoty baśniowy klimat.

W mroźny zimowy wieczór, na obrzeżach podgórskiej wioski, dwie kobiety - matka i córka - przemierzają zasypaną śniegiem drogę. Matka niesie zawinięte w kocyk dziecko, a córka idzie za nią, stawiając stopy w jej wyciśniętych w śniegu śladach. Rozmawiają opryskliwie, tonem pełnym niedopowiedzianych pretensji. Najpierw pieszo, a potem autobusem, wyprawiły się w odwiedziny do mężczyzny. Matka oskarża go o uwiedzenie jej niedorozwiniętej mentalnie, a fizycznie nad wiek rozwiniętej, nastoletniej córki, a co za tym idzie - o ojcostwo. Tłumaczy jednocześnie, że chce tylko ochrzcić w Boże Narodzenie przyniesionego w kocyku chłopca i zgodnie z jakimś niepisanym obyczajem nadać mu imię tegoż mężczyzny. Rozbawiony absurdalnym oskarżeniem mężczyzna wyrzuca kobiety z domu. Wracają w nocy pieszo, bo uciekł im autobus.

Następnego dnia w zatłoczonym przed świętami sklepie spotykają innego znajomego mężczyznę - poczciwego Matuszka, który oprócz wódki i zapachu do ciasta, kupuje ostatnią na półce butelkę żurku. Nie potrzebuje jej, robi to dla żartu, chcąc zakpić z czekającego na nią w kolejce aroganckiego turysty. Przed sklepem 
Matuszek wręcza żurek kobietom i przypomina sobie, że jego żona ma gdzieś w domu nieużywaną pierzynkę dla dziecka.

Wieczorem, przed Wigilią, kobiety przychodzą z dzieckiem do domu Matuszka. Młodsza wchodzi niechętnie, jakby się bała mężczyzn, którzy siedzą z Matuszkiem przy stole i piją wódkę. Powoli jednak oswaja się i nawet znienacka oskarża jednego z nich o to, że może być ojcem jej dziecka. Prowokuje tym kpiny i sugestie, że właściwie każdy tutaj i w okolicy, mógłby nim być, a najpewniej któryś z żołnierzy ze strażnicy, z „którymi się Iwonka prowadzała”. Upokorzone kobiety chcą odejść, kiedy nagle Matuszek - ku zaskoczeniu wszystkich - ogłasza, że to jego dziecko. Na nic zdaje się histeryczna reakcja żony Matuszka, która, protestując ujawnia, że sami nie mają dzieci, bo on miał wypadek i jest bezpłodny. Matuszek upiera się przy swoim i ustala datę chrztu. Kobiety wracają do domu zaśnieżoną drogą, dźwigając dziecko i pierzynkę. Córka idzie za matką, stawiając stopy w jej śladach.

Te trzy epizody z życia naiwnie borykających się $\mathrm{z}$ losem bohaterek, spisane na kilku zaledwie stronach, istotnie wydawały się przy pierwszym czytaniu materiałem zbyt ulotnym na filmową adaptację. Wprawdzie było tu sporo niedopowiedzeń i sugerowanych znaczeń, ale brakowało wyraźnej intensywności i stylistycznej ostrości, a przede wszystkim tego, co najważniejsze - konkretnej filmowej fabuły. Toteż mimo zauroczenia tekstem, odrzuciłem początkowo jakąkolwiek myśl o jego ekranizacji. Zamknięta w kilku scenach historia jawiła się jedynie szkicem kilkuminutowej etiudy.

A jednak po kilku dniach wróciłem do tego opowiadania. W kolejnym czytaniu tekst okazał się w istocie bardziej złożony i kusząco sugestywny. Subtelnie zakodowany pod powierzchnią mit religijny, do którego mimowolnie odnosimy losy bohaterek, dawał szansę na metaforę, a między wierszami lakonicznych opisów i arcyzabawnych dialogów tliły się wątki przejmującego ludzkiego dramatu. Naszkicowany był wprawdzie lekko i groteskowo, ale jednocześnie emanował jakąś mglistą i ponurą tajemnicą. Pokusa wyjaśnienia owej tajemnicy inspirowała najmocniej, sugerując jednocześnie, że sam proces jej wyjaśniania może stanowić niezłą oś dramaturgiczną filmu. W dalszym ciągu trudno było jednak wyobrazić sobie całą tkankę narracyjną potrzebną do wypełnienia owych „pięćdziesięciu kartek brudnopisu ze szkicem sceny na każdej z nich”, które - jak twierdzi David Lynch - są „niezbędnym zaczynem filmowego scenariusza".

W przypadku adaptacji często zdarza się nam, wiecznym tropicielom filmowych tematów, że zanim znajdziemy wreszcie idealny dla nas „materiał literacki”, nosimy w sobie jakiś zarodek filmu - amorficzny twór, którego nie możemy jeszcze ogarnąć. Mamy pojedyncze sceny, bezkształtne postaci ze strzępkami relacji czy też fragmenty błyskotliwych dialogów. Czasem jest to jakaś 
aktualna, poruszająca emocjonalnie lub atrakcyjna wizualnie sytuacja, a czasem kilka zapamiętanych z przeszłości obrazów, które przykleiły się gdzieś w zakamarkach wyobraźni i pączkują, tworząc grono całej efektownej sekwencji. Wszystko to, mimo że intensywnie zmysłowe, nie wiąże się nijak $\mathrm{z}$ tematami, które nas aktualnie interesują i zawieszone w próżni męczy jak senne marzenie - intrygujące i wyraziste dopóki śpimy, ale zbyt enigmatyczne, żeby je ogarnąć po przebudzeniu.

Ta niespójna wizja znika $\mathrm{z}$ czasem albo czeka uśpiona, aż jakiś konkretny pomysł albo inspirujący tekst literacki przywoła ją nagle jako coś dopełniającego lub wręcz absolutnie dominującego - wynoszącego projekt na nowe fascynujące poziomy. Bywa, że reakcja takiego połączenia jest nieomal wybuchowa i myślę, że tak się stało w przypadku tej adaptacji.

Nie umiem jednak powiedzieć, czy to właśnie opowiadanie Tokarczuk, z jego urzekającym klimatem i barwnymi postaciami, wymusiło tę reakcję, czy też ów tkwiący we mnie potencjał domagał się wreszcie jakiegoś kształtu i sprawił, że chwyciłem za tekst olśniewający wprawdzie, ale słabo rokujący pełny fabularny metraż.

Urodziłem się i dorastałem w miasteczku nieco większym wprawdzie niż podgórska wioska $\mathrm{z}$ opowiadania Tokarczuk, ale wystarczająco małym, abym mógł instynktownie wyłowić w Żurku całą gamę bliskich mi odniesień i analogii. Dotyczyły one nie tyle kulturowo-obyczajowej atmosfery, będącej praprzyczyną opisanych przez Tokarczuk zdarzeń, ale przede wszystkim świetnie naszkicowanych przez autorkę postaci, $\mathrm{z}$ ich charakterystycznym sposobem bycia, myślenia i mówienia. To właśnie one były bezpośrednim powodem mojej fascynacji tym tekstem i kiedy zdałem sobie $\mathrm{z}$ tego sprawę, uruchomił się nagle w mojej świadomości cały katalog ludzkich typów i przypadków zapamiętanych, a właściwie wchłoniętych przeze mnie nieomal organicznie w okresie dorastania. Nosiłem go przez lata w pamięci z nadzieją, że kiedyś wykluje się z niego jakiś może śmieszny, a może nostalgiczny film. Nie znalazłem jednak wystarczająco mocnej historii, która związałaby te wątki w jeden narracyjny twór. Korzystałem więc z jego zasobów wyrywkowo, aby przy okazji wcześniejszych realizacji wyostrzyć czasem jakiś epizod lub dowartościować postać. Tym razem jednak ta cała moja małomiasteczkowa menażeria, zachęcona swojskim klimatem opowiadania, wpraszała się do współpracy w sposób niezwykle natarczywy, z właściwą sobie prostacką gwałtownością.

Nabrałem pewności, że mam aż w nadmiarze to, czego szukałem. Układając konstrukcyjną drabinkę filmu, postanowiłem więc przenieść akcję dramatu z góralskiej wioski do miasteczka takiego samego jak moje.

Był to zabieg trochę nonszalancki, ale póki co - niezwykle skuteczny. Zyskałem konkret - grunt, po którym, rozbudowując fabułę, mogłem stąpać swobodnie; ze znajomością realiów i bez oba- 
wy, że wpadnę w pułapkę obyczajowych stereotypów. Niezwykle sugestywnie otworzyły się przestrzenie, których topografię świetnie znałem i już samo umieszczenie w nich akcji podsuwało nowe pomysły. To właśnie wtedy pojawiły się: torowiska z kolejarskim domkiem, szkoła, kościół, cmentarz, garnizon... Niby typowe dla wielu małych miasteczek miejsca, ale ja o każdym z nich mogłem opowiadać w szczegółach, które gwarantowały autentyzm i w sposób niemal magiczny mnożyły gamę kolejnych inspiracji. Będę o tym pisał w dalszej części tej pracy, ale podam teraz jeden przykład.

Aby scenę otwierającą film zabarwić nieco absurdem, wymyśliłem, że matka i córka, zamiast po zaśnieżonej drodze, będą szły po torach kolejowych, tak jak chodziła do szkoły zimą moja koleżanka mieszkająca za miastem w kolejarskim domku. Ten początkowo stylistyczny zabieg miał $\mathrm{w}$ efekcie ogromne znaczenie w konstruowaniu story i jej dramaturgicznego kontekstu. Nie tylko podkreślił wyobcowanie obu kobiet wobec miejscowej społeczności i nadał im w tej społeczności status, ale przede wszystkim zasugerował całą gamę bezcennych elementów, $\mathrm{z}$ których kluczowym była nieobecna w opowiadaniu, a niezwykle istotna w filmie, ponura i tajemnicza postać ojca - kolejarza.

Podobnie było $\mathrm{z}$ innymi miejscami na mojej topograficznej mapie. Kiedy w wyobraźni nanosiłem na nią trasę wędrówki bohaterek opowiadania, ożywały nagle przywołane z pamięci postacie i zdarzenia, mnożyły się motywy i z zadziwiającą łatwością przybywało pomysłów na sceny. W konspekcie pojawiały się ich kolejne numery i już wkrótce przekroczyłem nakazaną przez Davida Lyncha pięćdziesiątkę.

W istocie wymyśliłem wówczas sporą część fabuły późniejszego filmu, ale entuzjazm, z jakim pisałem drabinkę, sprawił, że nie zauważyłem $\mathrm{z}$ bardzo istotnego niebezpieczeństwa.

Kiedy w końcu przeczytałem całość, pojawiło się poczucie pewnego chaosu. Zdałem sobie sprawę, że pod naporem nowych atrakcyjnych postaci i sytuacji gubię gdzieś delikatną tkankę dramaturgiczną opowiadania Tokarczuk. Umykał gdzieś jego urzekający klimat, a misternie zawoalowane w tekście metafory i znaczenia zamieniały się w zbiór wspominkowych skeczów i rodzajowych anegdot.

Musiałem zweryfikować tę wymyśloną w euforii metodę, a to co zrobiłem, poddać wnikliwej selekcji. Do tego potrzebny był jakiś klucz. Spekulując czysto abstrakcyjnie, postanowiłem, że odwrócę teraz sytuację i tym razem wszystko, co do tej pory powstało, przefiltruję z powrotem przez pierwowzór literacki. Uczyniłem z tej myśli pewien rodzaj kanonu porządkującego pracę nad scenariuszem. Postanowiłem, że nie zrezygnuję z pomysłu umieszczenia akcji w mojej topografii, ale wykreowane w niej postaci - a co za tym idzie - motywy i ploty będą wynikały ze skojarzeń i sugestii wyczytanych w Żurku Tokarczuk. Każdy wypatrzony szczegół 
miał weryfikować to, co zostało już wymyślone, albo inspirować nowe wątki, teraz zgodne $\mathrm{z}$ duchem opowiadania. Wyszukiwanie cennych wskazówek w behawioralnych odruchach bohaterów, w strzępkach dialogów czy znaczących przemilczeniach, wszystko to stanie się swoistą grą wyobraźni, która ma określone reguły.

Od tego momentu, jak pamiętam, rozpoczął się właściwy etap konstruowania scenariusza. Towarzyszyło mu uważne wpatrywanie się w tekst literacki i odkrywanie na nowo znaczeń, ukrytych między jego wierszami.

Odtwarzając ten proces, przypomnę tylko jego najważniejsze momenty. Wiążą się one w sposób oczywisty z postaciami, gdyż to w nich samych i wokół nich znalazłem najbardziej istotne inspiracje. Fragmenty tekstu opowiadania będą tu przeze mnie przytaczane i analizowane chronologicznie, jednak omawiane postaci i wątki, a co za tym idzie - odnoszące się do nich fragmenty scenariusza - traktuję wybiórczo. Nie będzie więc łatwo przypadkowemu czytelnikowi zorientować się w szczegółach, a tym bardziej ogarnąć cały kształt filmu. Dlatego mam nadzieję, że tekst ten będzie czytana po obejrzeniu Żurku lub po lekturze jego scenariusza; jako tekst wspomagający ich ewentualną analizę.

Halina i Iwonka

Halina i Iwonka - matka i córka - zostały w opowiadaniu scharakteryzowane przez autorkę po mistrzowsku. Obie postacie, naszkicowane jakby od gestu i mówiące w dwudziestu niespełna linijkach lakonicznych dialogów, są niezwykle wyraziste.

Już na samym początku - sytuacja, kiedy idą ośnieżoną drogą i wypominają sobie nawzajem, która z nich jest winna, że się tak późno wybrały - sugeruje od razu dość złożoną relację i istotę konfliktu między nimi.

- Trzeba nam było wziąć wózek - powiedziała jedna do drugiej, gdy znalazły się na dawno nie odśnieżanej drodze do przystanku autobusowego. Starsza niosła dziecko zawinięte w kocyk, który teraz w szybko zapadającym mroku zrobił się szary, jakby był brudny. Młodsza szła za matką, stawiała stopy prosto w jej ślady na śniegu, tak było łatwiej.

- Trzeba nam było jechać w dzień, a nie po nocy - odezwała się znowu ta starsza.

- Trzeba było i trzeba było - powiedziała młodsza. - Nie zdążyłam.

- Nie trzeba się było tak stroić.

- Ty też się stroiłaś.

- Wcale się nie stroiłam. Nie mogłam znaleźć rękawiczek.

To Halina niesie na rękach dziecko swojej córki. Iwonka, idąc za matką, stawia odruchowo stopy w jej wyciśniętych w śniegu śladach - sama pozornie bezradna jak dziecko. Kiedy jednak matka atakuje ją, że się za długo „stroiła”, dziewczyna ripostuje krótko i celnie, wprawiając Halinę w zakłopotanie.

W dalszej części opowiadania ta sprzeczność staje się bardzo znacząca. Iwonka nie wydaje się upośledzona mentalnie, choć za 
taką uchodzi. Halina tłumaczy ludziom, że jej córka to „przecież dziecko w ciele dojrzałej baby" i słusznie w tym upatruje przyczyny nieszczęścia. Jednak istota tego nieszczęścia przekracza jej zdolność rozumienia.

Iwonka rzuca na oślep oskarżenia o ojcostwo i stwarza absurdalne sytuacje, ale wynikają z nich niezwykle ważne i inspirujące pytania: Czy jest wiejską „niezgułą”, rzeczywiście nieświadomą kto jej zrobił dziecko, czy może zdesperowaną dziewczyną, która broni się chaotycznie przed wyjawieniem jakiejś ponurej prawdy? Ta druga ewentualność dawała dużo większy potencjał $\mathrm{i}$ ten trop wybrałem. Nie zrezygnowałem jednak do końca z motywu mentalnej ułomności. Jakaś wyrazista skaza była tej postaci potrzebna i stąd w scenariuszu pomysł na jej „zagapianie się”, który potem kulminuje atakiem epilepsji. Ta specyficzna, zabarwiona mitycznym rysem choroba, wzbogaca postać Iwonki i niejako zdejmuje $\mathrm{z}$ niej odium winy.

Halina atakuje Iwonkę słowami: „Nie trzeba było się tak stroić”, a po ripoście córki „Ty też się stroiłaś”, twierdzi z zakłopotaniem, że sama nie stroiła się, tylko nie mogła znaleźć rękawiczek. W tym dialogu kryje się dosyć ulotna, ale bardzo istotna sugestia, że Władek - mężczyzna, do którego się wybierają, nie jest Halinie obojętny. Zdesperowana matka ma go oskarżyć o uwiedzenia córki, a tymczasem jej samej na nim zależy. Relacja ukształtuje się wyraźniej, kiedy skonfrontujemy ten szczegół z kolejną w opowiadaniu sekwencją rozmowy kobiet z Władkiem i poszukamy przyczyny naiwnej manipulacji Haliny. Da to początek zbudowanemu w scenariuszu "melodramatycznemu” wątkowi Haliny i Władka.

W przytoczonym powyżej fragmencie opowiadania jest jeszcze jeden drobny szczegół, który pomógł mi bardzo w konstruowaniu plotu Iwonki. Jest nim niebieski wózek dla dziecka. Matka wspomina o nim w pierwszej linijce dialogu. W opowiadaniu nie ma on większego znaczenia. Natomiast w filmie stanie się rekwizytem nieomal symbolicznym. Zaistnieje nie tylko jako groteskowy fetysz „kina drogi”, ale przede wszystkim jako istotny element narracji, dopowiadający skomplikowaną psychikę Iwonki - przedmiot jej dumy i miara jej człowieczeństwa. Dlatego też w scenariuszu tę pierwszą linijkę dialogu o wózku dałem Iwonce. Od tego momentu motyw wózka będzie się przewijał przez całą akcję, wspomagając znacznie wątek Matuszka; aż do finalnej sceny, w której Iwonka w swojej ostatniej kwestii wspomni właśnie o zepsutym wózku.

Oto jak wygląda w scenariuszu pierwsza scena filmu adaptowana $\mathrm{z}$ początkowego fragmentu opowiadania:

1. Plener. Tory kolejowe za miastem. dzień.

Biel wyostrza się i szarzeje. Pojawiają się sylwetki dwóch kobiet, idących jedna za drugą. Są tego samego wzrostu i podobnie szaro ubrane. Nawet oddychają tym samym rytmem, wypuszczając z ust kłęby pary. Co chwila 
podskakują śmiesznie, jakby utykały. Różnią się tylko wiekiem i domyślamy się, że to matka i córka. Starsza idzie pierwsza, niesie zawinięte w kocyk dziecko. Mówi rytmicznie i głośno, nie odwracając głowy.

HALINA

DESKA... DESKA ... DESKA... DESKA...

Dziewczyna stawia kroki, celując w ślady matki. Co jakiś czas jej noga trafia na przysypaną śniegiem belkę. Kobiety idą między szynami kolejowego toru. Matka potyka się nagle, a córka, jakby na to czekała, odzywa się pełnym pretensji głosem.

IWONKA

Trzeba nam było wziąć wózek.

HALINA

Potrzebny wózek na śnieg. Trzeba było jechać w dzień, a nie po nocy.

IWONKA

Trzeba było, trzeba było! Nie zdążyłam.

HALINA

Nie trzeba się było tak stroić.

IWONKA

Ty też się stroiłaś.

HALINA

Ja? Wcale się nie stroiłam. Nie mogłam znaleźć rękawiczek.

Matka wyjmuje spod kocyka gołą dłoń i odwraca się. Córka o mało na nią nie wpada.

Idą milcząc. Córka zostaje w tyle i po chwili zatrzymuje się. Stoi nieruchomo i patrzy w jedno miejsce. Nie widać tam nic oprócz kawałka ośnieżonego pola i pokrytych szronem głogów.

HALINA

Na co się gapisz? Iwonka!

Córka nie odpowiada.

Scena niewiele się różni od fragmentu opowiadania. W dialogach dwie dopisane kwestie Haliny: „Potrzebny wózek na śnieg." i „Na co się gapisz? Iwonka!" są związane z nowymi motywami, o których pisałem powyżej. Dodałem Halinie jeszcze jedną linijkę dialogu. Rytmiczne: „Deska... deska... deska...” wyrażało determinację i upór kobiety w dążeniu do celu. Ta kwestia będzie się powtarzała w filmie tak, jak powtarzalna kompozycyjnie będzie scena wędrówki po torach.

Przytoczyłem tu tylko pierwszą scenę, która wynika bezpośrednio z cytowanego wcześniej fragmentu opowiadania. Pośrednio jednak te kilka linijek tekstu Olgi Tokarczuk było zaczynem co najmniej kilkunastu scen filmu. Oto jedna z nich, w której matka po raz kolejny próbuje się dowiedzieć, kto jest ojcem dziecka Iwonki:

24. Wnętrze. pokój w domu Haliny. Dzień.

Halina opuszcza wzrok jakby uciekała przed surowym spojrzeniem męża. Przyklęknęła i podlewa kwiaty stojące na nocnym stoliku, przy ramce $\mathrm{z}$ fotografią.

HALINA

Iwonka, pamiętasz co ksiądz mówił o tym,

ŻE MĘŻCZYZNA I KOBIETA... NO O MIŁOŚCI. 


\section{IWONKA}

Kiedy?

Iwonka ubiera się. Włożyła właśnie biustonosz i nie może go zapiąć.

Halina wstaje z klęczek i pomaga jej.

HALINA

No, w zakrystii. Że muszą się razem położyć

I KOCHAĆ ZE SOBĄ, ŻEBY MIEĆ DZIECKO.

IWONKA

Miałam potem atak i nie wszystko pamiętam.

Iwonka wkłada bluzkę i zapina guziki.

HALINA

Mówiłaś mi kiedyś, że to wszystko wiesz.

IWONKA

Bo wiem.

HALINA

A kto się z tobą kładł? Tego nie wiesz.

Dziewczyna kręci głową i pochyla się nad łóżkiem, gdzie leży owinięte pieluchą dziecko.

IWONKA

$\mathrm{O}$, znowu się zlał. Już drugi raz.

Matka nie daje za wygraną i kiedy odbiera od córki mokrą pieluchę, łapie dziewczynę za ramię.

HALINA

A ten Pędzelek, kładł się z tobą?

Iwonka kręci głową i pokazuje na dziecko.

IWONKA

On się przeziębi i znowu się potem zleje.

Halina, jednym zdecydowanym ruchem, okrywa dziecko pierzyną i ściska mocniej ramię córki.

HALINA

Iwonka, ja się nie denerwuję

I TY SIĘ NIE DENERWUJ, DOBRZE?

Dziewczyna kiwa głową.

HALINA

Powiedz mi, kładł się z tobą?

IWONKA

Nie.

HALINA

No to co robił.

IWONKA

Trzymał.

HALINA

Jak cię trzymał? Pokaż.

Halina przyciąga córkę do siebie. Iwonka wspina się na palce, jak nauczyciel i niepewnym ruchem obejmuje matkę wpół.

HALINA

No i co, nic nie robił?

IWONKA

Macal.

HALINA

Pokaż, jak.

Iwonka kładzie rękę na biuście matki i zaczyna go ściskać. Halina podbi- 
ja jej rękę łokciem, ale za chwilę głaszcze ją przepraszająco i przenosi ją na podbrzusze dziewczyny.

HALINA

A tutaj? Nie macał cię tutaj?

Iwonka kręci głową.

HALINA

I nie wsadzał ci tutaj swojego...

Iwonka krzywi usta.

IWONKA

Nie wsadzał. Już kiedyś pytałaś.

Halina puszcza dziewczynę i chodzi wzdłuż łóżka. Iwonka od razu pochyla się nad dzieckiem i przewija je.

HALINA

A inni? Jakiś chłopak, chłop? Nie wsadzali ci?

Halina jest zdenerwowana. Gestykuluje i mówi coraz głośniej.

HALINA

Nikt, do jasnej cholery?!

Dziecko zaczyna płakać i Iwonka bierze je na ręce. Mimo to Halina podchodzi do niej i zaczyna nią potrząsać.

HALINA

Nikt cię nie pierdolił, nie ruchał,

NIE WSADZAŁ CI CHUJA DO ŚRODKA ...

Iwonka tuli dziecko i kręci głową. W porównaniu z matką jest spokojna i opanowana. Halina siada na łóżku i chowa głowę w dłoniach. Po chwili Iwonka odzywa się niepewnym głosem.

IWONKA

Może jak miałam atak

I DLATEGO NIC NIE PAMIĘTAM.

ŻOŁNIERZ

Ledwo zdażyly na autobus. Przyjechał zaparowany, prawie pusty. Na tylnym siedzeniu siedziała grupka nastolatków. Pewnie jechali do miasteczka na dyskotekę. Młodsza przyglądała im się spod oka, ale zachłannie. Taksowała dziewczyny, zwłaszcza jedna w skórzanej kurtce i w obcistych dżinsach. Matka zapytała córkę o coś cicho, ale ona tylko odwarknęła. Potem przetarła zaparowane szyby i patrzyła $w$ migajacy światłami mrok za oknem. Młodziez pojechała dalej, a one obydwie wysiadly na drugim przystanku tu, gdzie boczna droga łączyła się z dwupasmówka, po której przemykały $z$ hukiem duże ciężarówki.

Kolejny fragment opowiadania dał początek postaci, która paradoksalnie jest w nim nieobecna. Właściwie nie ma jej także w całym opowiadaniu. W ostatnim fragmencie opowiadania jeden z gości Mateusza wspomina, że Iwonka „prowadzała się z żołnierzami ze strażnicy”. To była bardzo istotna sugestia, w dodatku rzucona na podatny grunt.

W miasteczku, w którym mieszkałem, nie było garnizonu, ale były wojskowe zakłady otoczone wysokim murem i często grupki przyjezdnych żołnierzy pojawiały się w mieście. Nie przejawiano wobec nich jawnej wrogości. Starsze kobiety mówiły o nich „źołnierzyki”. Niektórzy z nich, szukając kontaktów z dziewczynami, dogadywali się z miejscowymi chłopakami, ale dziewczy- 
ny z miasteczka, które „prowadzały się z żołnierzami”, zawsze były na cenzurowanym. Łatwo sobie wyobrazić, o ile ostrzejsze musiały być relacje między miejscowymi a żołnierzami ze strażnicy w sytuacji małej przygranicznej miejscowości, gdzie większość ludzi żyje z przemytu. Tak konfliktowe tło wydawało się idealne dla rozwinięcia wątku, który moglibyśmy tu nazwać melodramatycznym.

Po lekturze opowiadania niewiele wiemy o uczuciach Iwonki. Groteskowa i śmieszna nie wzbudza innych refleksji niż ciepłe politowanie. Jej życie wewnętrzne nie jest istotne. Krucha i szara egzystencja, w trafnym zestawieniu $\mathrm{z}$ religijnym mitem, wywołuje w stopniu absolutnie wystarczającym sarkastyczną zadumę nad ludzkim losem i boskimi wyrokami.

W scenariuszu postać Iwonki, musiała mieć precyzyjnie zbudowaną konstrukcję psychologiczną i wynikającą z niej emocjonalność. Potrzebne były elementy, które by ją określały. Dotyczyło to w ogromnym stopniu mrocznej przeszłości determinującej zachowania dziewczyny, ale także tego, co będzie się działo z jej emocjami na naszych oczach - w bieżącej akcji filmu.

Jednym z elementów tej konstrukcji miał być właśnie wątek melodramatyczny. Oczywiście skrojony na miarę Iwonki, z całą jej dziecięco-naiwną, a jednocześnie mroczną okaleczoną wrażliwością. Osaczonej i broniącej się na oślep dziewczynie potrzebne było jakieś niewinne oczyszczające uczucie - takie, które i pozwala na chwilę odetchnąć i goi piekące ukłucia. Tak zrodził się pomysł na wątek Żołnierza.

Oto jak zapisałem w scenariuszu scenę w autobusie. Iwonka i Żołnierz spotykają się tu po raz pierwszy:

3. Wnętrze. Autobus. Dzień.

Autobus ruszył. Matka przeciera ręką zaparowaną szybę. Za szybą mężczyzna, który zatrzymywał autobus, otrzepuje ze śniegu wytartą ortalionową kurtkę i podnosi z ziemi starego kolarskiego „Jaguara”. Ze spokojem przyjmuje wymówki od stojącej nad nim żony.

HALINA

(rozbawiona)

Matuszek się wywrócił. Pod samym sklepem.

Halina wychyla się z fotela i kasuje bilet.

HALINA

Też, zimą jeździć na rowerze.

Iwonka nie interesuje się ani Matuszkiem, ani kołyszącą dziecko matką. Patrzy na koniec autobusu, gdzie rozsiadła się grupka rozbawionych nastolatków. Rozmawiają głośno i puszczają z radia muzykę. Są wśród nich dwaj młodzi żołnierze. Jedna z dziewczyn ma obcisłe dżinsy i skórzaną kurtkę, a pod nią bluzę z mieniącym się wizerunkiem smoka. Dziewczyna kołysze się na kolanach chłopaka, chociaż obok jest wolne miejsce. Iwonka przygląda się jej spod oka, z półotwartymi jak u dziecka ustami. 
Siedzący pod oknem żołnierz zauważył Iwonkę. Ma sympatyczną twarz i niebieskie jak chabry, śmiejące się oczy. Mruga do Iwonki, udając zaloty, ale po chwili zdejmuje czapkę i otwiera usta naśladując głupkowatą minę dziewczyny. Słychać śmiechy. Iwonka też się śmieje. Zdejmuje z głowy brzydką wełnianą czapkę i rozpuszcza włosy.

\section{HALINA}

Może byś dziecko trochę przytrzymała?

IWONKA

(opryskliwie)

Teraz?

Matka daje za wygraną. Iwonka odpina płaszcz. Rozpychający bluzkę biust kontrastuje $\mathrm{z}$ jej dzieciną twarzą. Z końca autobusu słychać gwizdy uznania.

Szyba zdążyła już zaparować. Matka przeciera ją znowu. Nie wiadomo, czy jej otwarte szeroko oczy wpatrują się w migoczącą światłami szarość, czy w odbitą w szybie sylwetkę córki.

W tej scenie i poprzedzającym ją krótkim ulicznym pasażu, zostaje wprowadzona do filmu, $\mathrm{z}$ całym jej wymyślonym na potrzebę scenariusza „kolarskim” sztafażem, postać Matuszka. Będę o niej pisał w dalszej części pracy.

Pojawia się także inny, bardzo ulotny, ale niosący ciekawe znaczenia wątek koszulki ze smokiem. Nosi ją siedząca z żołnierzami dziewczyna. Iwonka wymusi potem na matce kupienie takiej samej, mówiąc, że „tatuś by jej taką na pewno kupił”. Halina przymierza potem $\mathrm{w}$ domu, po kryjomu, koszulkę córki i przez moment w lustrzanym odbiciu wydaje się młodsza i zalotna, jak za dawnych lat. $\mathrm{W}$ chwilę potem, jak na życzenie, pojawia się przed domem Władek i zostaje u Haliny na noc. Iwonka zakłada tę koszulkę także w scenie kulminującej wątek ojca - kiedy mówi matce o „tajemnicy z tatusiem”.

Trudno nazwać ten wątek magicznym. To raczej ledwo zauważalna dygresja albo zwiewna nostalgiczna refleksja na temat magii, którą - jeśli chcemy - odnajdujemy czasem w banalnej codzienności. Wszystko tu jest na wskroś realistyczne, zgodne z logiką, ale jednocześnie trochę tajemnicze i skutecznie, choć nie nachalnie, stopniuje nastrój.

Najważniejszym jednak efektem sceny w autobusie jest zawiązanie wątku Żołnierza, który zgodnie z oczekiwaniem rozwinął się potem $w$ bardzo znaczący $w$ filmie plot. Zainspirował on kilka pełnych emocji scen i wygenerował ciekawe epizodyczne postacie. Przede wszystkim jednak przysłużył się stopniowemu odkrywaniu wewnętrznego świata Iwonki.

Zwracając uwagę na żołnierza, Iwonka wybiera kogoś z zewnątrz, bo w jej mniemaniu nikt miejscowy pewnie by jej nie zaakceptował. Spotyka go potem kilka razy, zupełnie przypadkowo, a kiedy rodzi się jakieś uczucie czy może raczej odwzajemniona 
sympatia, wszystko się nagle komplikuje. Przymuszona okolicznościami, naciskana przez matkę, a jednocześnie wiedziona jakąś irracjonalną nadzieją - oskarża go niesłusznie o gwałt.

46. Plener. Dziedziniec strażnicy. Zmierzch.

Iwonka uśmiechnięta, powoli jak we śnie, idzie wzdłuż szpaleru żołnierzy. Za nią kroczy Halina i kapitan. Całą grupę prowadzi sierżant taksujący żołnierzy przenikliwym spojrzeniem. Iwonka prawie nie patrzy na twarze. Dopiero przed drugim szeregiem zwalnia i zatrzymuje się w miejscu, gdzie stoi chłopak. Wskazuje go matce i kapitanowi. Chłopak nie odwzajemnia uśmiechu Iwonki. Stoi z opuszczoną głową. Dziewczyna niepewnie spogląda na matkę. Czar prysnął. Wszystko powraca do normalnego rytmu wraz z szorstką komendą sierżanta.

\section{SIERŻANT}

Z szeregu wystąp!

Wskazany przez Iwonkę żołnierz wychodzi przed szereg i staje na baczność.

\section{KAPITAN \\ (do Iwonki)}

To ten?

Chłopak zerka niespokojnie na Iwonkę.

\section{KAPITAN}

(głośniej)

Czy to ten żołnierz.

Matka dotyka ramienia Iwonki; dziewczyna kiwa głową. KAPITAN

Nie słyszę.

IWONKA

Ten.

Kapitan zbliża się do żołnierza. KAPITAN

Czy znasz tę dziewczynę?

CHŁOPAK

Nie znam.

KAPITAN

Nigdy jej nie widziałeś?

CHŁOPAK

To znaczy widziałem ją ze dwa razy.

\section{KAPITAN}

Gdzie?

CHŁOPAK

Niedawno. Raz w autobusie i raz w sklepie.

\section{KAPITAN}

Widzę, że dobrze pamiętasz.

\section{CHŁOPAK}

(po namyśle, $\mathrm{z}$ uśmiechem)

Podobała mi się.

Słychać śmiechy. Spojrzenia Iwonki i żołnierza krzyżują się na moment, ale chłopak szybko odwraca wzrok.

KAPITAN

Jej matka twierdzi, że ma piętnaście lat i jest niedorozwinięta. Wiedziałeś o tym? 
Iwonka przestępuje z nogi na nogę i opuszcza głowę. Chłopak nie patrzy na nią.

CHŁOPAK

(ciszej)

Nie.

KAPITAN

Podobno zrobiłeś jej dziecko.

CHŁOPAK

(zdumiony)

Ja? To niemożliwe. Ja przecież...

KAPITAN

Ona twierdzi, że ją zgwałciłeś.

Stojący na baczność chłopak z trudem utrzymuje równowagę. Kręci głową. KAPITAN

Ojcostwo można udowodnić. Jeśli kłamiesz. Zostaniesz oskarżony o gwałt. Na nieletniej. Będziesz siedział.

Iwonka przysuwa się do matki, jakby się chciała za nią schować. Sierżant wpatruje się w nią świdrującym spojrzeniem.

ŻOŁNIERZ

Nie kłamię. Ja przecież...

Halina odrywa się od wózka i staje między chłopakiem a kapitanem.

HALINA

Panie oficerze. Po co tyle kłopotu? Żeby ochrzcić dziecko i dać mu imię od ojca?

KAPITAN

Tu nie chodzi o chrzest, tylko o gwałt.

Sierżant podchodzi do kapitana.

SIERŻANT

To niemożliwe. Panie kapitanie to jest kot.

Kapitan unosi brwi. Chłopak z trudem przełyka ślinę i patrzy z wdzięcznością na sierżanta.

KAPITAN

Jak długo służysz?

CHŁOPAK

Dopiero sześć miesięcy.

KAPITAN

Skąd jesteś?

CHŁOPAK

Z Warszawy.

KAPITAN

( $\mathrm{z}$ ironią)

A ty byłaś kiedyś w Warszawie?

Słychać śmiechy. Iwonka kręci głową. Chłopak też się śmieje.

KAPITAN

No więc, jak to może być jego dziecko?

Iwonka ma łzy w oczach. Odwraca się bez słowa i biegnie w stronę bramy. Sierżant odprowadza dziewczynę wzrokiem i wymienia znaczące spojrzenie z kapitanem.

SIERŻANT

(do chłopaka)

Widzisz kocie? Nawet sobie nie zaruchałeś, a miałbyś dzieciaka.

Halina rusza za Iwonką, ciągnąc wózek wzdłuż szpaleru rozbawionych żołnierzy. 
Ten wątek jest w finale sarkastyczny i gorzki, ale jednocześnie w jakiś przewrotny sposób optymistyczny. Kończy się sceną prawdziwego gwałtu, który ma być zgodnie z kodeksem „fali” karą za pomówienie, a jednak paradoksalnie przynosi dziewczynie upragnione oczyszczenie. Kiedy Iwonka odsłania „kominiarkę” i rozpoznaje żołnierza rzuconego na nią przez kolegów - tuli się do niego jak w wyśnionej scenie miłosnej - właśnie osiągnęła swój cel.

Władek to mężczyzna, do którego wybrały się w zimowy wieczór Halina i Iwonka, by oznajmić mu, że jest ojcem dziecka. To właśnie dla niego się tak obie stroiły. W opowiadaniu Tokarczuk jest to pierwsza postać, z którą rozmawiają. Jest także świetnie scharakteryzowana i jako jedyna w opowiadaniu, choć występuje tylko w jednym epizodzie, ma w miarę konkretnie opisany kontekst:

Minęly rozświetlony świątecznie motel i dotarły do smażalni ryb. Przez chwilę stały przed napisem „Zawsze coca-cola”, która jak ogromny czerwony księżyc oświetlała fasadę świeżo odnowionego domu.

- Zawołamy go tu, czy jak to zrobimy? - zapytała matka.

- Ty idź, a ja tu poczekam z dzieckiem.

Starsza kobieta weszła i po chwili wróciła.

- Nie ma go. Jest $\mathrm{w}$ domu.

Popatrzyły na siebie krótko i ruszyły na podwórko.

Zaszczekał przywiązany do budy pies. Zapaliło się automatycznie światło. Śnieg pokrył miłosiernie cały budowlany bałagan - stosy desek, paki styropianu opakowane $\mathrm{w}$ folię, piramidy pustaków. Pan Władek budował garaż.

Wyszedł do nich. Postawny rudawy mężczyzna w swetrze robionym na drutach, którego rękawy pruły się niemiłosiernie. Popatrzył na nie zdziwiony.

- A cóż wy tu robicie o tej porze? - zapytał bez powitania.

- Mamy interes - powiedziała starsza.

- Tak? - zapytał przeciągle jeszcze bardziej zdziwiony.

- Możemy wejść?

Zawahał się, ale tylko sekundę, prawie niezauważalnie. Wpuścił je do środka, do sieni świeżo otynkowanej, z grudkami cementu, które trzeszczały im teraz pod butami. Weszły do zabałaganionej kuchni. Chyba majstrował coś przy zlewie, bo szafka była odsunięta od ściany i odsłaniała tajemnice rur i kolanek.

$\mathrm{Z}$ tego fragmentu dowiadujemy się, że Władek ma smażalnię ryb, obok niej dom z garażem, który właśnie remontuje, a za chwilę dowiemy się też, że ma jakąś rodzinę. Jego status jest tu określony i bardzo ważny dla relacji z obiema kobietami. Buduje dystans, który $\mathrm{w}$ oczywisty sposób ustawia je, $\mathrm{z}$ ich naiwną pretensją, na z góry przegranej pozycji. W trakcie rozmowy, kiedy zawiązuje się konflikt, pojawia się kilka istotnych szczegółów sugerujących, jak wzajemne relacje postaci mogły wyglądać w przeszłości:

- Możemy usiąść? - zapytała starsza. 
Ustawił im dwa krzesła, prawie na samym środku kuchni, sam zapalił papierosa i oparł się o tę odsuniętą szafkę. Dopiero teraz zobaczył dziecko i uśmiechnął się.

- Chłopiec czy dziewczynka?

- Chłopiec, chłopiec - odpowiedziała młodsza i odwinęła dziecko z kocyka. Odsunęła mu z oczu niebieską, wełnianą czapeczkę. Dziecko spało. Jego mała pomarszczona buzia skojarzyła mu się ze świeżo wyłuskanym orzechem laskowym. Była brzydka.

- Śliczny - powiedział. - A jak ma na imię?

- Jeszcze nie ma - powiedziała młodsza wesoło.

- Władysław - rzuciła szybko starsza.

- Władysław? - zdziwił się on. - A kto teraz daje dziecku na imię Władysław?

Skrzywił się. Zaciągnął się papierosem.

- A więc, co to za interes?

- Ty masz na imię Władysław i on Władysław... - ciągnęła starsza.

- Może być i Władysław, kto powiedział, że nie.

Umilkli. Mężczyzna strzepywał popiół na podłogę.

- No więc?

Kobieta odwróciła szybko wzrok na czubek opartego o ścianę karnisza i powiedziała $\mathrm{w}$ tamtym kierunku:

- To jest twoje dziecko, Władek. Idą święta, więc chcemy je ochrzcić.

- Tyś, Halina, chyba ochujała. Jak to może być moje dziecko? No Iwonka

- zwrócił się dziewczyny - jak to może być moje dziecko, co wy obie wygadujecie?

Iwonka przygryzła wargi i zaczęła szybko kołysać dziecko. Obudziło się i krótko zapłakało.

- Kto jest ojcem? - zapytał.

- Ty jesteś ojcem. To twoje dziecko.

Mężczyzna wstał i zgasił butem papierosa.

- Wyjdźcie stąd, no już, obie.

Wstały z ociąganiem. Iwonka zsunęła niemowlęciu na oczy niebieską czapeczkę.

- No, już, już - poganiał je.

- No dobra, Władek, w takim razie ojcem jest twój syn, Jacek - powiedziała nagle matka już przy drzwiach nie odwracając się.

- Był tutaj na Wielkanoc - powiedziała zaczepnie Iwonka.

- Wynoście się.

Drzwi za nimi zamknęły się. Stały w milczeniu na brudnym wydeptanym śniegu. Za chwilę zgasło światło.

- No i co? - zapytała Iwonka matkę.

- A co ma być? Nic.

Z tej sytuacji jasno wynika, że Władek jest raczej rówieśnikiem Haliny, a sposób, w jaki rozmawiają, świadczy o tym, że dobrze się znają lub może znali przed laty. Trudno określić stopień ich zażyłości. Obcesowość Władka przy powitaniu sugeruje raczej, że to jakaś zadawniona relacja z przeszłości. Znając dobrze Halinę, mężczyzna czuje, że może się spodziewać kłopotów. Wierzymy Władkowi, kiedy zaprzecza insynuacjom Haliny, zwłaszcza, że ta natychmiast przerzucała winę na jego syna, który „był tutaj na Wielkanoc". 
To działanie Haliny na oślep daje do myślenia. Wyczuwamy, że wymyśliła całą intrygę, a jej determinacja wynika $\mathrm{z}$ beznadziejnej sytuacji, w jakiej się znalazła. Władek ma smażalnię i dom. Jest zamożny, a więc idealny na opiekuna, którego obie potrzebują. Ale czy chodzi tylko o pieniądze?

Mężczyzna, mimo że szorstki, wydaje się sympatyczny. Na początku reaguje dosyć ciepło, jakby był kimś z rodziny albo bliskim znajomym. Pomyślałem, że mogli być kiedyś parą... zanim Halina wyszła za mąż, a teraz, kiedy męża nie ma, dawne sentymenty powracają. Tylko dlaczego Halina wybrała tak desperacki i beznadziejny pomysł na odnowienie dawnej zażyłości? Może po śmierci męża Haliny są już na powrót kochankami i Władek nagle przestał się z nią widywać. Zaraz potem Iwonka rodzi dziecko. Halina jest świadoma, że Iwonka może być dla Władka atrakcyjna. Jest do niej podobna - wygląda jak ona sama, przed laty, kiedy Władek ją kochał. Halina musi sprawdzić i wyeliminować najczarniejszy z możliwych wariantów.

Taka interpretacja motywów działania Haliny wydawała się nieco dziwaczna, ale jednocześnie bardzo inspirująca. Potrzebo- 
wałem jakiejś zawiłej intrygi, która rozpoczęłaby z impetem jeden z ważniejszych wątków filmu i uwiarygodniła jego przyczynowoskutkowe związki. Dlatego postanowiłem pójść tym ryzykownym tropem, uważnie pilnując jego wiarygodności.

Scena wizyty u Władka została w scenariuszu niemal wiernie adaptowana $z$ tekstu opowiadania, wraz ze wszystkimi zawartymi w nim sugestiami. Nie było w niej jednak miejsca na zbyt dosadne ujawnienie owych ukrytych intencji Haliny. Dlatego uczyniłem to w następnej scenie, kiedy Halina i Iwonka kłócą się po wyjściu od Władka.

9. Plener. Podwórko Władka/Parking przed smażalnią. Wieczór.

Furtka zamyka się z trzaskiem. Gaśnie reflektor oświetlający budowlany bałagan na podwórku Władka. Matka i córka stoją za furtką - na błotnistym parkingu przed smażalnią. Pierwsza odzywa się Iwonka.

IWONKA

No i co?

HALINA

(zdenerwowana)

A co ma być? Nic.

Halina zaciąga się i dopiero teraz wyrzuca, dopalony do końca okurek papierosa. Jej ręce trzęsą się ze zdenerwowania.

IWONKA

Jak to nic?

HALINA

Daj mi dziecko.

Halina jedną ręką obejmuje mocno zawinięte w kocyk dziecko, a drugą wymierza córce policzek, a kiedy ta odsuwa się, dogania ją i bije raz za razem po głowie.

HALINA

(krzyczy)

Co mówiłaś, że to tutaj? Co mówiłaś?

IWONKA

(z płaczem)

Ja mówiłam? Ja mówiłam? Ty mówiłaś! Ja mówiłam, że nie wiem.

HALINA

Jak to nie wiesz, głupia? Jak można nie wiedzieć?

IWONKA

Nie wiem i już!

Przed smażalnię wybiegli jacyś ludzie i „kwadratowy” pracownik Władka w białym fartuchu.

Iwonka szlocha. Matka zamierza się na nią jeszcze raz, ale w tym momencie słychać z góry suchy trzask i gaśnie neonowe światło na billboardzie Coca-Coli. Z podwórka dobiega skowyt psa. Ludzie przed smażalnią patrzą do góry, jak na zaćmienie. Neon, tak nagle jak zgasł, zapala się znów. Potem buczy i znowu gaśnie, aby po chwili rozbłysnąć już na dobre.

W opowiadaniu ta sytuacja zawierała się w krótkim dwuliniowym dialogu. Rozbudowałem ją, dodając awanturę, aby zasugerować, że to Halina w gruncie rzeczy manipulowała Iwonką, a nieszczęsna wizyta u Władka była jej desperacką próbą odzyskania go. To tu właściwie zaczyna funkcjonować w scenariuszu moja wysnuta $\mathrm{z}$ tekstu 
koncepcja wątku Haliny i Władka, który - podobnie jak wątek Iwonki i Żołnierza - możemy nazwać w cudzysłowie „miłosnym”. Zobaczmy jak on się rozwija w dalszej części scenariusza. Tych sytuacji nie ma oczywiście w opowiadaniu, ale możemy się zorientować, jak bardzo nawiązują do tego, co wynikało dla mnie z wizyty u Władka, opisanej przez Olgę Tokarczuk.

34. Plener. Podwórko przed domem Haliny. Noc.

Halina otwiera drzwi. Niesie wiadro z mydlinami.

HALINA

Wejdź, Władek.

Władek wychodzi z cienia. W ręku trzyma niewielką, ustrojoną już, plastikową choinkę. Milczy zakłopotany. Dopiero, kiedy Halina wskazuje głową drzwi, omija ją bez słowa i przeskakując stopnie, wchodzi do środka.

Halina wylewa mydliny na śnieg, ale nie wraca od razu do domu. Stoi $\mathrm{w}$ drzwiach $\mathrm{z}$ pustym wiadrem i oddycha szybko. Jest zimno i z jej ust wydobywają się kłęby pary. Para unosi się też nad wytopioną w śniegu, czarną kałużą. Halina spogląda w niebo. Jest czyste i pełne gwiazd. Jedna $\mathrm{z}$ nich spada błyszcząc jeszcze przez chwilę.

35. Wnętrze. Kuchnia w domu Haliny. Noc.

Halina uśmiecha się. Ma zamknięte oczy. Jej twarz porusza się rytmicznie. Po chwili przesłania ją głowa Władka, który pojękuje w miłosnym uniesieniu. Podparty na łokciach unosi się i opuszcza. Twarz Haliny wykrzywia grymas rozkoszy. Jęki Władka stają się coraz głośniejsze i Halina zasłania mu usta dłonią. W końcu jego głowa opada na wałek kozetki. Leżą nieruchomo.

Choinka, którą przyniósł Władek, ma zapalone lampki i stoi na telewizorze. Smuga księżycowego światła zabarwiła sinym kolorem wiszące na sznurze pieluchy.

Błyska zapalniczka. Oboje jednocześnie pochylają się nad płomieniem i zapalają papierosy.

WŁADEK

Z tym dzieckiem to Iwonka wymyśliła?

HALINA

Iwonka, Iwonka. Akurat ona ci coś powie.

WŁADEK

To tobie tak odbiło?

Władek zabiera rękę spod głowy Haliny i zaciąga się głęboko.

HALINA

A co miałam myśleć? Przychodziłeś do mnie, przychodziłeś i nagle przestałeś.

WŁADEK

Bo mam żonę i dzieci, to przestałem.

HALINA

Akurat jak się okazało, że Iwonka w ciąży?

WŁADEK

(z sarkazmem)

Akurat wiedziałem, że ona w ciąży.

HALINA

A myślisz, że przedtem, to nie widziałam jak na nią patrzysz? Jeszcze Witek żył.

Władek siada na kozetce. 
WŁADEK

Coś ci się, Halina, z głową porobiło.

Władek wstaje z kozetki i odgarnia ręką wiszącą pieluchę, która przykleja mu się do twarzy. Słysząc łkanie Haliny siada z powrotem i kładzie dłoń na jej plecach.

WŁADEK

Dla niej jestem wujek i tyle. A ty weź się w garść, bo głupiejesz.

Halina odwraca głowę do ściany.

HALINA

Sama już nie wiem. Czasem myślę, że Witek to przeze mnie pod pociąg skoczył.

WŁADEK

Jak przez ciebie? Przecież wszystkim rozpowiadał, że się pod ostatni pociąg rzuci. A mundur kolejarski, a biało-czerwona szarfa? Głupi i tyle.

HALINA

Ty tak o nim? Przecież on to dla ludzi. Wszyscy się biedy bali. Sam byłeś na kolei, zanim się za przemyt wziąłeś.

Halina siada na kozetce i opuszcza podciągniętą aż do biustu koszulę. Władek milczy.

HALINA

Jak by tu teraz jeszcze pociągi chodziły, sama bym się rzuciła.

Halina gasi papierosa w popielniczce. Chce wstać, ale Władek zatrzymuje ją.

WŁADEK

Dlaczegoś ty, Halina, za Witka wtedy wyszła, a nie za mnie. Zupełnie by było inaczej.

Halina zwija się nagle jak ślimak i przytula do piersi Władka.

HALINA

Gówniarze byliśmy wtedy, Władziu.

Władek sięga ręką do stołu i gasi papierosa. Nieruchomieje na moment, kiedy za plecami Haliny w głębi kuchni słychać ciche skrzypnięcie i drzwi do pokoju otwierają się same. W mroku, w rozkopanej pościeli świecą, jak na starym obrazie, odsłonięte biodra i wyłożona na pierzynę noga Iwonki. Nie odwracając wzroku od drzwi, Władek podwija koszulę Haliny i zaczyna całować jej nagie piersi.

Władek pokazuje się $\mathrm{w}$ filmie $\mathrm{w}$ kilku zaledwie scenach, ale jest postacią bardzo ważną, jak chodzi o dramaturgię filmu. Jego szorstka „normalność" wnosi do rozedrganego wątku kobiet trochę spokoju i nadziei. Wiemy, że już za późno na bezinteresowny powrót do dawnych namiętności, ale Halina odradza się przy nim na moment, a jej stłumiona po śmierci męża kobiecość rozkwita na powrót.

Wydawałoby się, że Halina osiągnęła zamierzony cel - Władek powrócił i opiekuje się nimi. A jednak jakaś destrukcyjna siła nie pozwala na stabilizację. Mroczna tajemnica córki i związana z nią obietnica złożona mężowi na grobie każe brnąć dalej. Halina odchodzi.

Tekst powyższy jest fragmentem przygotowywanej publikacji Ryszarda Brylskiego Między wierszami, czyli adaptacja nietypowa (DVD „Żurek”) Wydawnictwo PWSFTviT w Łodzi. 